\title{
AMOR Y PSIQUE. \\ HERMENÉUTICA DE UNA FÁBULA DE LAS ARTES FIGURATIVAS AL TEATRO DE CALDERÓN
}

\author{
Enrica Cancelliere \\ Dipartimento di Letterature e culture europee (DILCE) \\ Facoltà di Lettere e Filosofia \\ Università degli Studi di Palermo \\ Via delle Scienze - Edificio 12 \\ 90128 Palermo (Italia) \\ enricacancelliere@libero.it
}

[Anuario calderoniano (ISSN: 1888-8046), vol. extra, 1, 2013, pp. 21-48]

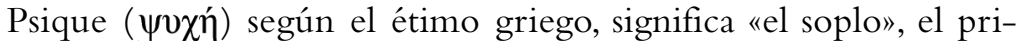
mordial aliento vital, por traslación, también «alma». Sin embargo, esta significación se da in progress, puesto que aquel originario aliento vital tiene que pasar por la muerte para hacerse "alma», es decir, un ídolo incorpóreo ( $\varepsilon i ́ \delta \omega \lambda \sigma v)$, una especie de divinidad inmortal en todo y por todo, parecida por su semblante a un ser humano, por lo tanto, capaz de amar, sufrir, gozar, pero libre de su corporeidad: por fin una pura imagen viviente. Morir en el mundo terrenal, separarse del cuerpo, del cual se hace parte como aliento vital, quiere decir también juntarse con alguna divinidad, y, a través de esta unión, llegar a ser to- 
talmente una imagen ideal, y divina, del cuerpo. Es propio de las ninfas, desde siempre y para la eternidad, esta imagen viviente ${ }^{1}$. Porfirio nos cuenta en su De Antro ${ }^{2}$ que las ninfas en origen son soplos y por eso van buscando la parte más profunda de una caverna - el antro de las ninfas según Homero- allá donde puedan volver a mezclarse con las fuentes para regenerarse. $\mathrm{Y}$ así esos soplos vitales llegan a ser en todo y por todo jóvenes inmortales e incorpóreas, con alas que les permiten ascender de los abismos a los cielos, como se nota en este fresco del primer siglo después de Cristo [Imagen 1].

Esas jóvenes podían tener ligazones amorosas tanto con seres humanos que llegaban al antro a través de la entrada del norte, como con dioses que entraban por la puerta del sur. En efecto, los Griegos llamaban ninfas (vó $\mu \varphi \alpha \mathbf{l})$ a las esposas durante el rito del Himeneo, por el hecho de que llegaban a ser la personificación de las mismas divinidades gracias al rito de la iniciación de las bodas. Respecto a esto, la Psique de la fábula de Apuleyo $^{3}$ puede considerarse el arquetipo: la belleza de esta joven es tan sorprendente que llega a ofender a la misma Venus; después de varias peripecias llega a un lugar inaccesible y misterioso donde se une en abrazos amorosos con un dios, pero con la condición de no ser vista. La infracción de este tabú la obliga a sufrir dificiles pruebas, según el esquema de la fábula ritual, hasta cuando, concluido el recorrido iniciático, podrá unirse en matrimonio con aquel joven - del cual ahora estamos informados de que es Cupido, hijo de Venus- Juntos ascenderán al Olimpo.

Calderón en $\mathrm{Ni}$ Amor se libra de $\mathrm{Amor}^{4}$, aunque se aleja sustancialmente de la Fábula de Apuleyo, construye, según la misma complejidad hermenéutica, la imagen de la protagonista, Siquis, y hace propio el valor esotérico de la Fábula: Siquis es el cí $\delta \omega \lambda o v$, la imagen perfecta de un semblante humano, pues, como es propio de las ninfas, es «la imagen de la imagen»; la representación de la imagen por sí misma. La actividad de la imaginación elabora la imagen que se da para ser admirada no sólo a través de la vista de la mente, deseada, glorificada, idolatrada, sino también vejada y perseguida. Siquis es la pro-

${ }^{1}$ Ver Agamben, 2007.

${ }^{2}$ Ver Porfirio, 1986, pp. 36-85

${ }^{3}$ Apuleio, 1972.

${ }^{4}$ Cito por la edición de Valbuena Briones, 1966, Obras completas. Tomo I, Dramas. Todas las citas se refieren a esta edición con indicación de la página. 
yección de los deseos del hombre según su propio imaginario; es su sombra, pero una sombra que resplandece más que el semblante del cual es su proyección; es el anhelo de aquella hermosura hacia el paradigma que el deseo mismo formula. No por casualidad en Apuleyo la hija de Psique y Amor se llama Voluptad.

Sin embargo, Calderón en las dos versiones del auto sacramental de Psiquis y Cupido, (respectivamente de 1640 y 1665), nos ofrece una interpretación cristológica según la cual el Alma, a través de varias tribulaciones, después de haber abrazado la fe, llega a conseguir el matrimonio con Cristo. Aquí Calderón se ajusta a una interpretación hermenéutica de la Fábula, tal y como se había desarrollado a lo largo de la Edad Media y que se encuentra hasta en Dante. Sin embargo, también esta interpretación se fija dentro de la compleja elaboración que va del neoplatonismo pagano al neoplatonismo cristiano. A este proposito conviene recordar que San Agustín apreciaba mucho la Fábula de Apuleyo.

Ahora bien, lo sorprendente es que Calderón en la comedia palaciega asuma la Fábula en su totalidad según su vigencia en el mito y rito paganos, y la elabore según una hermenéutica filosófica que va del Platonismo al neoplatonismo hasta el Hermetismo.

La obra se construye según los cánones de la comedia: reducción del número de los personajes; introducción de los graciosos, Friso y Flora, contrapunto materialista y empírico con respecto a las parejas aristocráticas y divinas; eliminación de las peripecias novelescas y de las pruebas relativas a arcaicas iniciaciones rituales; organización del espacio escénico a través de la alternancia entre los dos teatros regios - el palacio regio paterno y el palacio del esposo divino- y los dos loci amoeni contiguos. La escenografia reproduce efectos maravillosos: los cambi a vista y una isla de encantamiento. Hay que añadir que la pieza configura la «fiesta palaciega» neopagana: bailes y músicas acompañan cortejos de personajes reales y/o mitológicos alternándose con tableaux estáticos de fuerte valor icónico ${ }^{5}$.

Esta coreografia y ambientación manifiestan una reproducción autocelebrativa y ostensiva de la corte tal como acaecía en el teatro inglés de los masques, en el francés de las fêtes galantes y en el teatro italiano de los Intermezzi y de la Pastorale. La puesta en escena en su

\footnotetext{
${ }^{5}$ Ver Cancelliere, 2001, pp. 117-132.
} 
totalidad se desarrolla según una metonimia de tableau, acompañados por cantos en eco y retornelos que siguen oyéndose aún por «dentro». Así, analogamente a lo que se realizaba en la fête barroca, según comenta Starobinski ${ }^{6}$, sustentada por el eco amplificado de las músicas, la sucesión de los teatros ofrece a la mirada un desarrollo metonímico que es mero gozo de la visión por sí misma. El desarrollo de los tableaux, reforzado por el preciosismo del verso corto en un juego de correspondencias, intecambios simétricos, sonoros y conceptuales, agudezas, bisemias y falsos silogismos conceptuosos, se hace cargo de suscitar la deixis de las posturas con fuerte connotación icónica, y de actualizar, gracias a la palabra, el admirable movimiento escénico.

Por consiguiente podría suponerse que la fête galante «Psyche» de Moliere-Lully, que estrena en el Palais-Royal de Luis XIV en 1671, tuvo como modelo la «fiesta real» de Calderón.

Ahora bien, ¿cómo el dramaturgo asume este mitema literario e iconológico dentro de su poética? Para esta representación encomiástica y ostensiva de la imagen paradigmática de la Belleza, nuestro autor elabora estrategias poéticas que se desarrollan a lo largo del texto a través de tres recorridos: primero el de la relación con las taxonomías icónicas que vienen de las artes figurativas y plásticas como celebración del mito de Psique y Amor o de mitemas que con éste pueden relacionarse; segundo, el del metateatro que reelabora la estructura diegética de la comedia y los lenguajes escenográficos y dramáticorepresentativos de la representación-música, sobre todo de tradición italiana; y por último, el recorrido hermenéutico para el estatuto de la imagen desde Platón hasta el neopaganismo neoplatonizante manierista y barroco.

A través del análisis textual intentaremos poner de manifiesto estos tres recorridos: la referencia a las taxonomías de la tradición icónica; el metateatro; y la cuestión iconológica con respecto al estatuto de la imagen.

La jornada primera comienza representando, según nos informa la didascalia, un "campo entre palacio del rey de Gnido y el templo de Venus». Un cortejo inaugural irá desfilando, entre bailes y cantos, del palacio al templo. No sólo las didascalias explícitas sino también las

\footnotetext{
${ }^{6}$ Ver Starobinski, 1975, pp. 57-72.
} 
implícitas permiten visualizar mentalmente toda la fiesta ${ }^{7}$. De hecho, la palabra poética calderoniana se hace siempre guía del movimiento escénico confirmando de esta manera la supremacia del decorado verbal con respecto a la escenografia —ó ois según Aristóteles- que presupone implícita en la lectura toda posibilidad de representación en el nivel mental ${ }^{8}$.

Nos informa la primera didascalia: «Sale un Coro de música y detrás Selenisa, suelto el cabello y coronada de flores y con la copla que se canta y representa, dando vuelta al tablado [...]». Se trata de la hija del rey de Gnido Atamas, al que seguirán las dos hermanas con sus respectivos cortejos [Imagen 2]. Es interesante recordar que las fuentes iconográficas, manieristas y barrocas, a partir del Veronesi insisten en las representaciones de cortejos reales que, en cambio, no caracterizan la Fábula de Apuleyo. Lo interesante de la didascalia, en esta apertura de la fiesta que se ofrece como el «triunfo de la Belleza», es aquel detalle de Selenia que baila "suelto el cabello» y coronada de flores que no puede dejar de evocarnos representaciones pictóricas de ninfas como connotación del Eros cósmico; un ejemplo entre muchos posibles: La Primavera de Botticelli [Imagen 3]. La misma iconografía dibuja la hermana Astrea que, al salir con el coro segundo, «da vuelta al tablado» acompañada por sus damas, todas corornadas de guirnaldas». Luego con el coro tercero aparece Siquis con sus damas llenas de guirnaldas, bailando. Como en el tableau pictórico, así en el tableau dramático calderoniano la representación del triunfo de la belleza de corte construye la metáfora cosmológica: Selenia, Astrea y Siquis son nombres que ponen en relación las esferas celeste con el soplo vital de la naturaleza y de los hombres, según una visión neoplatonizante. Las comparaciones hiperbólicas de Arsida y Lidoro, que hacen referencia a los repertorios simbólicos de las flores y astros, piedras preciosas y esferas celestes, vienen al autor de las formas poéticas culteranas y de una visión idealizada de la belleza que había sido elaborada por el pensamiento filosófico neoplatónico a partir de la Academia Chiaregiana a León Hebreo en adelante.

Sucede que, mientras el aplauso de la muchedumbre a las tres bellísimas jóvenes es creciente, Arsida y Lidoro, los dos jóvenes reyes pro-

7 Ver Arellano, 1995, pp. 411-445.
${ }^{8}$ Ver Cancelliere, 2000, pp. $78-85$ 
metidos esposos a las dos primeras - presentes de incógnito, ansiosos de ver a sus futuras esposas- manifiestan una admiración creciente a cada aparición, hasta declarar el deseo ardiente que les invade viendo a la última, Siquis, que desgraciadamente para ellos se quedará para siempre insatisfecho. Ambos ven, admiran, sin ser vistos, y no conociendo ni el objeto de su promesa ni el del deseo. Un esquema en quiasmo que, como se verá, se conjurará con la visión inversa de las jóvenes, igualmente secreta e igualmente insatisfecha: ante la belleza absoluta, la pulsión escópica tiende sus tramas y genera inexorablemente la falta de lo que busca. Pero el objeto de esta falta - convienen los dos- es exquisitamente subjetivo, una obsesión por la imagen contemplada, que hace suspirar a Lidoro «aquello que atrae se llama / un no sé qué» ${ }^{9}$. La imagen de la amada atrae la vista hacia un "más allá», una Otredad con respecto a la imagen misma. Eso ocurre por el hecho de que la formulación de la imagen se elabora a través del proceso de reminiscencia, tanto el de ascendencia platónica relativo al mundo pagano, como el cristiano «a lo divino» o el analítico.

Durante los tres desfiles atraviesa el espacio teatral el eco de un retornelo que invita a ir al templo de «Venus y Amor», para ofrecer adoración al simulacro de Venus. El canto de Siquis, con el coro en eco, enciende aquel deseo de adoración incitando a correr con «planta veloz [...] a rendir el corazón» a la diosa la cual «vibra en sus ojos [...] los arcos de diosa y las flechas de un dios».

Nunca veremos a Venus, ni como simulacro ni como viva presencia. Por una significativa elección del autor se apercibirá a la diosa sin llegar jamás a verla. Sin embargo la imagen metafórica que formula Siquis suscita en el imaginario, gracias a una síntesis cabal, el simulacro divino con sus atributos: en sus ojos, que lanzan dardos resplandecientes, vibra el amor absoluto connotado metonimicamente por los símbolos del arco y de la flecha. Entre las muchas referencias icónicas merece la pena recordar la de Venus y Amor en el techo del «Camerino di Venere» en el Palacio Tè de Giulio Romano ${ }^{10}$ [Imagen 4]. Y del mismo pintor el simulacro de Venus que en tromp-l'oeil se erige en un octágono de la «Sala dei Cavalli» [Imagen 5].

${ }^{9}$ Ver Porqueras Mayo, 1972, pp. 11-59.

${ }^{10}$ Ver Belluzzi, 1998 y 2006. 
La llegada del noble Anteo, primo de las tres hermanas, es causa de una irreparable desilusión en Lidoro y Arsida: la tercera joven es Siquis, que él adora profundamente y cuya belleza vuelve a pintar con metáforas preciosas que la asimilan a la perfección del cosmos. Sin embargo, Anteo introduce un nuevo tema fundamental: Siquis como doble, aunque humano, de Venus; y como "alma» que, con respecto al simulacro, representaría el doble viviente.

Desde el comienzo, pues, Siquis se presenta como ninfa de Venus, la diosa reina de las ninfas. De hecho dice Anteo:

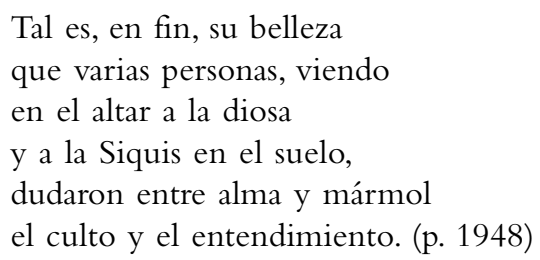

Y el alma se traslada de Siquis al simulacro. En efecto, Anteo está contando lo que hace poco ha acaecido en el templo, que consiste en el hecho de que el simulacro, en presencia de Siquis, empieza a desarrollarse pronunciando el terrible oráculo:

Infelice tu hermosura, Siquis, será, pues tu dueño un monstruo ha de ser. (p. 1948)

Sin embargo, Anteo se alegra pensando ser él mismo aquel monstruo, en el sentido de "monstruo de amor» en contra al «monstruo de hermosura».Y sigue contando el sacrilegio perpetrado por la gente en tumulto que rompe el simulacro; el llanto de Siquis echada en el suelo y el dolor del padre.

Pero, ¿por qué la joven quiere postrarse ante lo que queda del simulacro de la diosa? ¿Por qué teme tanto su venganza? El subestrado edípico que estructura la Fábula arcaica y pasa a significar el cuento de Apuleyo está bien presente en Calderón; en efecto estos acontecimientos, que forman parte del relato, se colocan en una «escena virtual», es decir una escena que no puede ser representada en el tablado y que los espectadores pueden ver sólo con los ojos de la mente. 
El hecho es que la «ninfa», doncella de Venus, sería idealmente asimilable a su hija. La terrible madre del imaginario, pues, por el sacrilegio en contra de su simulacro, perpetra su vengaza contra Siquis, la cual puede contar con el amor del padre que la prefiere a sus hermanas, mientras la verdadera madre nunca aparece.

Está claro, ahora, por qué, regresando al palacio, todos se postran a los pies de Siquis que, en lágrimas, abraza a su padre, mientras el cortejo vuelve a celebrar su belleza con bailes y cantos que se repiten con insistentes retornelos:

\author{
Pues que Venus envidia \\ la beldad suya, \\ Siquis es la diosa \\ de la hermosura. (p. 1949)
}

Un fresco en el techo de la "Camera di Psique» de Giulio Romano representa el triunfo de Psique venerada como una diosa gracias a la mirada que se desarrolla hiperbólicamente a lo largo del eje vertical (p. 206).

En el recorrido de ida y vuelta al Palacio de un suntuoso cortejo aristocrático el núcleo profundo de la Fábula queda representado. Ésta es la función escénica de la Parade que en la época caracterizaba la fête galante en el teatro de corte de Luis XIV.

Luego aparece Cupido, según iconografia, con arco y flechas, que con duras palabras reprocha a Siquis haber intentado competir con «la que es madre del fuego, / con ser hija de la espuma».Y, amenazando a Siquis, dice:

En su seguimento iré, y de un arpón y otro arpón

aljaba su corazón a merced del arco haré.

De uno a otro pasaré con sangrienta furia brava. (p. 1950)

Pero su venganza terminará con la caída del mundo en el caos de la noche de la pasión irracional: 
Tema el sol, túrbese el día, la noche anticipe fría sus sombras. Todo sea horror. (p. 1950)

Gracias a un admirable efecto de scaena ductilis aparece un «teatro de jardín» del Palacio Real.

"iAy, hermosa Siquis mía!», llora el padre, manifestando con su afecto exclusivo que la belleza es sinónimo de infelicidad: la belleza hay que ocultarla para que no sea fuente de escándalo. Y así la joven se oculta de manera que ni el sol pueda verla. Y Atamas debe admitir que lo que ha hecho es lo necesario: «en que no la vea / nadie en el mundo. Quizá no viéndola, cesará / la envidia de Venus» (p. 1951). El motivo está en Apuleyo, según el cual nada bello ni bueno existe si otro no lo ve, aunque lo vea con invidia. Y se encuentra también en las Confesiones de San Agustín ${ }^{11}$, donde el tema de la envidia se relaciona al de la pulsión escópica (in-videre).

En tanto las hermanas de Siquis se esconden entre la vegetación para ver a sus novios. La función deíctica de las miradas de los cuatro personajes, si por una parte connota este jardín como «verde laberinto» - recordemos a este propósito la admirable «fabrica» de Boboli, realizado por los mismos arquitectos que luego obrarán en el teatro del Coliseo - por otra va costruyendo el espacio intricado a través de trayectorias que especularmente representan sus pasiones. El mismo Giulio Romano ha proporcionado un desarrollo labiríntico a su narración pictórica de Amor y Psique, inspirándose en la heráldica de los Gonzaga.

Sin embargo, con una metafora del locus amoenus que es también meta-teatral y meta-iconológica al gracioso Friso que le pregunta: "¿Qué os parecen estos cuadros?» Arsida responde: "Abreviados paraísos / donde la naturaleza se valió del artificio» (p. 1953). El hecho es que Lidoro y Arsida anhelan ver otra vez la divina imagen causa de su pasión. Así dirá Arsida en un aparte: «Infelice soy, / Siquis, pues no consigo / arder un punto a los rayos / de tus dos soles divinos» (pp. 1953-1954). En este jardín, laberinto de amor, las trayectorias de las miradas nunca alcanzan el objeto de deseo. La analogía de esta escena con los trueques de amor y las pasiones no correspondidas de la

${ }^{11}$ Sant' Agostino, 1970, pp. 43-45. 
«silva encantada» de Sueño de una noche de verano de Shakespeare es interesante porque confirma la circulación de motivos macro-textuales en la cultura europea.

Igualmente en este laberinto de Amor las bellas jóvenes parecen estatuas; las imágenes verdaderas jóvenes, mientras Arsida y Lidoro se quejan porque en vano siguen buscando la imagen de Siquis.Y es éste el lugar donde puede llegar Cupido con sus flechas para clavar el pecho de Siquis con su propia mano y no a ciegas. Sin embargo, en este jardín-laberinto la ninfa extenuada se ha rendido al sueño. Según una iconografía codificada, el dios como un áspid entre las flores se acerca a la ninfa durmiente y al mirarla se queda suspenso: "pues aunque duerme su vida, / su hermosura está despierta. / ¡Qué hermosa es! Mas mi rabiosa / ira, ¿en qué suspensa está?»(p. 1956). Pero mientras el dios, víctima de su mismo veneno de amor, saca la flecha que herirá a ambos, Siquis, que en sueños imaginaba monstruos, murmura: «Monstruo, detente».Y puesto que el dios le toma la mano llevándola a su boca, será la ninfa, asombrada y ofendida, la que llegará a herirlo con su misma flecha [Imagen 6]. Cupido ahora, llamando a testigo los Cielos, exclama «Ni Amor se libra de Amor». Sin embargo en este laberinto de amor también las miradas de deseo de Astrea y Selenisa, escondidas entre la vegetación, convergen hacia Cupido.

La intriga de las miradas ha enmarañado todo enredo engañoso representando desilusiones y anhelos insatisfechos en un dispositivo teatral bien codificado.

El episodio está pintado al fresco en una luneta de la Camera di Psiche de Palacio Tè: [Imagen 7] el dios alado pendiendo con su flecha sobre la bella durmiente, que está soñando imágenes monstruosas, llega a despertarla. En otro fresco esas imágenes monstruosas, que a Siquis le aperecen en sueño, asumen la forma de un sátiro, insidia salvaje para la ninfa en el locus amoenus que acojerá a los dos amantes. La joven, apoyada en el tronco, reclinando la cabeza en las espaldas y con las piernas cruzadas, reelabora el modelo clásico de "Ariana abandonada». La representación así de los dos topoi, que se carga de 'Evép $\gamma \varepsilon 1 \alpha$ gracias al valor plástico, antes escultóreo de la pintura del maestro Giulio Romano modelada en el dibujo, parece coincidir con el pensamiento iconológico de Calderón que, como hemos visto, asune el «mármol» y el «alma» como materia imaginaria de sus simulacros. 
Pero el motivo iconológico de la Ninfa y del Satiro monstruoso es de sólida tradición veneciana y se difundió en Europa, como en la obra de Poussin, donde la ninfa podría ser la misma Venus.

La jornada segunda comienza con un teatro de mar. A causa de una tormenta la nave que llevaba a Atamas con su hija Siquis, Anteo y otros se precipita contra los escollos de una isla encantada, según otro topos teatral macrotextual de la época ${ }^{12}$.

El decorado marino, un monte inaccesible en Apuleyo, refuerza el mitologema del "paisaje salvaje y desolado, como lugar de encantanientos y apariciones prodigiosas relacionados con el motivo del mar y de la isla ${ }^{13}$. Además, entre tierra y mar, se va connotando un cosmos especular donde podrá realizarse la unión entre Psique y Cupido en la apoteosis final. El «teatro de mar» desliza hacia el «teatro de bosque» cuando de la oscuridad de la silva se oyen venir «bramidos de horribles brutos / lamentos de aves funestas» según nos informa Aristeo (p. 1959). Atamas, que había salido de su patria con el intento de llegar al monte Oeta donde hubiera debido cumplir con el sacrificio de Siquis según el oráculo de Júpiter, decide, en cambio, dejarle allí abandonada. La joven, entretanto, después de un concitado parlamento en que manifiesta su profunda aflicción, especular al caos de la naturaleza, se desmaya. Al despertarse la pobre infeliz puede ver la nave que se va alejando al horizonte. Su desolado lamento se modela en el topos de la "Ariana abandonada» que, en la forma del melodrama, había encontrado en la Ariana de Monteverdi (1608) el ejemplo más relevante.

Combatida entre sentimientos opuestos: odio por aquella nave enemiga y por su padre, pero al mismo tiempo piedad, Siquis, llegada al límite, exclama: «triste, turbada, ciega, / muda, absorta, confusa, helada y muerta, / desesperada» (p. 1962). A causa de esta desazonada desesperación, su imagen llega a fijarse en el icono de la infelicidad que es propia de la belleza destinada desde siempre a la violencia y al abandono:

Mas un padre y un amante, y que entrambos la aborrezcan,

12 Ver Fernández Mosquera, 2006, espec. pp. 15-42 y 109-157.

${ }^{13}$ Sobre los espacios dramáticos en el teatro de Calderón, ver Arellano, 2001, pp. 77-106. 
no sólo la historia, pero

la fábula aun no lo acuerda.

¡Ay infeliz de aquella que a estrenar

ejemplares nació expuesta! (p. 1963)

Y su angustia va creciendo al alejarse la nave al horizonte, mientras va cayendo una terrorífica noche bajo la forma icónica de la «madre de las tinieblas", que la deixis temporal ofrece a la ówıs. Tinieblas sobre tinieblas, el teatro está precipitando en la oscuridad absoluta como en un lienzo tenebrista.

He aquí que la scaena ductilis abre a la vista un teatro de gruta por donde "sale una Ninfa con un velo en el rostro y una hacha encendida en la mano, y canta» (p. 1964). La ninfa invitando a Siquis a seguirla hasta las entrañas de la cueva, al reparo de las iras de Venus, le da la bienvenida como a una deidad, mientras dos Coros en forma de salvajes la van repitiendo en eco.

Al llegar a lo profundo de la gruta se le aparece de repente a Siquis, gracias a la scaena ductilis, un "palacio real» tan suntuoso - un verdadero teatro de la maravilla ${ }^{14}$ — que no puede dejar de admirar con estupor y no sólo por su magnificencia sino también porque el reino de las tinieblas se ha vuelto en reino de la luz.

He aquí que aparece el dios Cupido el cual, apagando el hacha que había traído la ninfa, le ruega a Siquis que escuche sus palabras de amor pero que jamás intente verlo.

El naufragio y todo lo que ha acaecido ha sido preestablecido, explica el dios, que ahora, gracias a la fuerza de su amor, la proclama, acompañado por el Coro, reina «de cuanto el mar incluye, / de cuanto el sol engendra / y la tierra produce» (p. 1964). Y él mismo llega al punto de llorar, con el objeto de detener a la bella Siquis que, espantada, intenta escapar. De lejos se oye la voz de Anteo que se había echado al mar para ir a salvarla y la ninfa desesperada intenta responderle, a pesar del peligro de que la misma Venus llegue a oírla. Un caos de voces, suscitado por el mismo dios al fin de proteger a la ninfa de las iras de Venus, cierra la jornada segunda.

La jornada tercera se abre con un teatro de jardín, el de Cupido, envuelto en una oscura noche, perfectamente simétrico al jardín diur-

${ }^{14}$ Ver Arellano, 2003, pp. 41-56. 
no de Gnido de la jornada primera. De forma inversamente especular al palacio real del rey Ataman totalmente en plein air corresponde ahora el de Amor, colocado en las entrañas de la tierra. En este tercer acto se asiste, gracias a la escoena ductilis, a una sorprendente alternancia de los teatros canónicos de la «fiesta real»: teatro regio, de mar, de silva, de gruta (o de infierno), de jardín. Ausente sólo el «teatro de cielo» que está presente incluso en la Fábula de Apuleyo.

De hecho, la diégesis construye una visión atornillada en abismo que es la metáfora fundante de la obra: la belleza como voluptuosidad y pasión que el Eros suscita no puede sublimarse ascendiendo a los cielos sino quedarse en las entrañas más profundas de la tierra. Es el Eros, pues, que reside en el fondo del alma y en los abismos del imaginario. De hecho, Siquis es proclamada reina y diosa en las profundidades de la tierra, morada de las Ninfas.

Siquis ha llegado a fijarse en un icono mítico. Será la graciosa Flora quien lo explique cuando le dice a Friso que la misma joven: «está persuadida, a que es / algún dios que a verla baja / de las esferas, bien como / por Endimión Diana, / por Dafne Apolo, por Leda / Júpiter» (p. 1968).

De forma sorprendente Calderón usa los maravillosos efectos de la escenografia "all'italiana» para visualizar la metáfora que construye el pensamiento filosófico desde Platón, Plotín, Séneca, San Agustín hasta la Escolástica, es decir la vida como representación de sombra; la vida como teatro, ilusión, sueño. Gracias a sus poderes mágicos Cupido, puesto a las espaldas de Siquis, hace aperecer la visión del palacio real de Atamas y las bodas de sus hermanas entre pompas y galas, pero a condición de "que a mí no me has de ver / a la trémula, a la escasa / luz para que lo veas / tú, las mismas sombras traigan» (p. 1970).

Cuentan que el teatro nació cuando un chamán hizo aparecer detrás de un telón a una joven bailando para aliviar el alma del Mandarino, imagen de la que estaba enamorado y que había perdido ${ }^{15}$. Y el mito platónico de la caverna metaforiza en forma de representación el anhelo de conocimiento y los deseos del alma. Sin embargo, el topos es totalmente barroco: de la caverna del mago Próspero a la admirable Ilusion Comique de Corneille, hasta esta pieza caldero-

${ }^{15}$ Sobre este relato ver, D'Amico (al cuidado de), Enciclopedia dello Spettacolo, vol. III, vox «Cina: Teatro delle ombre», 1975, p. 786. 
niana en que se reproduce su acmé de entropía metafórica. En efecto, en la visión ilusoria los cortejos de los Imeneos se mezclan con los suspiros de los novios por la ausencia de Siquis, y sobre todo, la queja del padre: «Ay perdida Siquis mía! / Todo esto sin tí no es nada». Y a ella que le responde, no oída, «¡Padre! ¡Señor!», el dios invisible, abrazándola tiernamentele murmura: «No te escucha; / que todo eso es sombra vaga» (p. 1971).

Llegados a este punto queda de manifiesto el significado profundo de esos cortejos que bailan «bassadanze» y «salterelli» de buen agüero, en auge a partir del siglo XV en las cortes italianas bajo el influjo del platonismo, gracias sobre todo a Domenico da Piacenza, llamado el «Domenichino», coreógrafo y humanista que, siguiendo a Aristóteles (Sulla memoria e la reminiscenza ${ }^{16}$ ), afirmaba en su De la arte di ballare e danzare. De Arte saltandi et chores ducendi ${ }^{17}$ que hacía falta «bailar por fantásmata», es decir, pasando de una imagen a otra, y aún que esas imágenes están cargadas de memoria y por eso se fijan en la imaginación como iconos, generando un proceso mental de anámnesis. De eso deriva que lo esencial para la danza no es el tiempo (ritmo) sino la duración, la persistencia de sus fantásmata. Aby Warburg ${ }^{18}$ estaba fascinado por el Domenichino y Aristóteles: el renacimiento del paganismo y la iconología como ciencia vienen de ahí.

En Ni Amor se libra de Amor Calderón nos ofrece la más cumplida realización teatral celebrando la imagen a través de una «Fiesta» representada en su máximo valor icónico.

Entre tanto Cupido, enternecido por la tristeza de su amada, determina siempre con sus poderes una bonanza de mar de manera que la nave de Atamas pueda dar la vuelta a la isla encantadora.

El regocijo de Siquis termina, como en Apuleyo, a causa de las intrigas de sus hermanas invidiosas que incitan a Siquis a que vea en la cara al monstruo del cual es infeliz esposa.

Por fin baja la noche en el jardín de Cupido que se había puesto impaciente por prolongar Apolo el día atrasando la carrera de su carro de oro de un horizonte a otro. Este intenso icono luminístico ha-

16 Aristotele, 1983.

${ }^{17}$ Domenico da Piacenza, De Arte saltandi et choreas ducendi. De la arte di ballare et danzare, manuscrito f. Ital 972, Bibliothèque Nationale de Paris, fechado 1425.

18 Ver Warburg, 1980. 
bía sido realizado por Giulio Romano en la "Camera del sole e della luna ${ }^{19}$. Sin embargo, se trata de un mitolgema icónico que atraviesa la pintura y la poesía manieristas y barrocas y en particular se encuentra en las comedias palaciegas de Calderón.

Por fin llegamos al núcleo del drama: el tálamo de los dos amantes; la dulzura del abrazo y la insidia que en él se anida. «Siéntase Siquis en el suelo, y reclínase Cupido junto a ella» (p. 1978): la ninfa canta una dulce nana para adormecer al dios niño, mientras todos los elementos del universo con su armonía lo inducen al sueño. En este momento la ninfa intenta pasar a la acción. La construcción del icono llega ahora a su máximo valor de entropía. El puñal en una mano y en la otra el hacha, Siquis se queda suspendida pendiendo sobre el bello joven durmiente. Pero cuando la luz deja ver al amado en toda su belleza, Siquis turbada exclama:

\author{
¿Qién vio más bella pintura? \\ ¿Quién más perfecta escultura? \\ El que dijo que éste es \\ un monstruo, dijo bien, pues \\ es un monstruo de hermosura. (p. 1979)
}

Y se queja de que cuando estaba adormecida, él la estaba mirando, y que ahora que consigue verlo es él el que está durmiendo. La estructura en quiasmo refuerza la especularidad de la imagen que ahora se fija en un icono, que ya fue gongorino ${ }^{20}$ : «El bulto vio, y, haciéndolo dormido, / librada en un pie toda sobre él pende» (vv. 227228) y luego

de sitio mejorada, atenta mira, en la disposición robusta, aquello que, si por lo süave no lo admira, es fuera que lo admire por lo bello. (vv. 273-276 21 )

19 Ver Belluzzi, 2006, pp. 133-134.

${ }^{20}$ Góngora, Fábula de Polifemo y Galatea, octavas 33-35. Ver Cancelliere, 2006, pp. $130-134$.

${ }^{21}$ Cito de la edición de Parker, 1983. 
Pero ahora es Siquis quien mirando con estupor al bello joven exclama: «¿Quién al ver no queda ciego / la perfección que a ver llego? / Suspensa le estoy mirando» (p. 1979). El episodio, ya presente en Apuleyo, ha inspirado a varios pintores entre los cuales recordemos a Iacopo Zucchi y su Psiche e Amore dormiente, en la Galleria Borghese [Imagen 8], donde el diseño manierista inaugura el decorativismo barroco.Y Giulio Romano, que lo pinta en un octágono del techo donde, de forma sorprendente, el iluminismo lívido construye una visión metafísica. Sin embargo, el topos icónico de la ninfa que se suspende a la vista de un bello joven durmiente, en el bosque de amor, está presente en la pintura manierista y barroca con todo su valor de alegoría platonizante. Recordemos, entre otros muchos ejemplos: Venere e Adone del Veronesi; Diana ed Endimione del Carracci [Imagen 9]; etc.

Ya estamos en el fin de «fiesta». Cupido, que se ha herido con una gota de aceite caliente de la hacha de Psique, enfurecido, huye, pero con el fin de proteger a su amada de las iras de Venus. El mundo se oscurece y un paroxismo lo hace precipitar en el caos. Exclama Atamas: «Sin duda que el cielo todo / se desploma de sus ejes» (p. 1980). Y, como en el mito de Euridice, Siquis se queja: «verle quise, y le he perdido por verle!» (p. 1980). Pero Cupido vuelve atrás porque Venus se ha conmovido por el llanto de los dos amantes, y del cataclismo del mundo vuelve a surgir el locus amoenus que acoge el himeneo.

No es por casualidad que Giulio Romano, desmintiendo a su maestro Raffaello, que había pintado el Olimpo en el techo de la Farnesina, haya desarrollado, a lo largo de dos paredes, la escena del banquete nupcial de Amor y Psique, un locus amoenus terrestre que mezcla flores, fuentes, las cornucopias con las Náyades, dioses, sátiros y bestias en una especie de renovada Edad de Oro, y en el centro la espléndida pareja divina echada en el tálamo nupcial con su hija, la Voluptad. Luego, en el centro del techo, Amor y Siquis están pintados en un vuelo que va desarrollándose a lo largo de un eje vertical en una visión aberrada, hacia el rayo de luz deslumbrante, como llamas de un volcán [Imagen 10].

Sin embargo, nos parece sorprendente el cromatismo de esos cielos, que se abren en el techo, pintados al óleo con matices de gris, de azul-noche, de naranja y rojo sombrío que parecen surgir más de las profundidades infernales que de las esferas celestes. Lo que es sorprendente es que la visión aberrada contre-plongée del pintor es inver- 
samente especular a la visión plongée del poeta que a través de las tinieblas llega a una luz sepultada en las entrañas de la tierra.

Visión del abismo de la pasión colocado en los cielos o representación de la subida al Hiperuranio gracias a la imagen «bella» colocada en el palacio de los abismos, el tema de Amor y Psique fue para el pintor y el poeta la obra maestra de la trasgreción: la de la vista que precipita hacia su apoteosis. 


\section{BiBLIOGRAFía}

Agamben, G., Ninfe, Torino, Bollati Boringhieri, 2007.

Apuleio, Le Metamorfosi o, L'asino d'oro, ed. F. Carlesi, Firenze, Sansoni, 1972. Arellano, I., «Valores visuales de la palabra en el espacio escénico del Siglo de Oro", Revista Canadiense de Estudios Hispánicos, 19, 3, 1995, pp. 411442.

— «Espacios dramáticos en los dramas de Calderón», en Calderón. Sistema dramático y técnicas escénicas", ed. F. B. Pedraza et al., Almagro, Universidad de Castilla-La Mancha, 2001, pp. 77-106.

— «Espacios de la maravilla en los dramas de Calderón», en Loca ficta: los espacios de la maravilla en la Edad Media y Siglos de Oro, ed. I Arellano, Madrid / Frankfurt, Iberoamericana / Vervuert, 2003, pp. 41-56.

Aristotele, Della generazione e della corruzione. Dell'Anima. Piccoli trattati di storia naturale, Modena, Franco Cosimo Panini Editore, 1998, 2 vols.

Belluzzi, A., Palazzo Te a Mantova. The Palazzo Te in Mantua, Modena, Franco Cosimo Panini Editore, 1998, 2 vols.

- Giulio Romano. Amore e Psiche a Palazzo Te, Modena, Franco Cosimo Panini, 2006.

Calderón de la Barca, P., Obras completas, tomo I, Dramas, ed. Á. Valbuena Briones, Madrid, Aguilar, 1966.

Cancelliere, E., Introducción a P. Calderón de la Barca, El príncipe constante, Madrid, Biblioteca Nueva, 2000.

— «Calderón y el teatro de corte», Cervantes, 1, 0, 2001, pp. 117-132.

- Góngora. Itinerarios de la visión, trad. R. Bonilla y L. Garosi, Córdoba, Diputación de Córdoba, 2006.

Fernández Mosquera, S., La tormenta en el Siglo de Oro. Variaciones funcionales de un tópico, Madrid / Frankfurt, Iberoamericana / Vervuert, 2006.

Góngora, L. de, Fábula de Polifemo y Galatea, ed.A.A. Parker, Madrid, Cátedra, 1983.

Piacenza, D. da, De Arte saltandi et choreas ducendi. De la arte di ballare et danzare, manuscrito f. Ital 972, Bibliothèque Nationale de Paris, fechado en 1425.

Porfirio, L'antro delle ninfe, con testo greco a fronte, introduzione e note di L. Simonini, Milano, Adelphi Edizioni, 1986.

Porqueras Mayo, A., Temas y formas de la literatura española, Madrid, Gredos, 1972.

Sant’ Agustino, Confessioni, ed. P. Roita, Brescia, «La Scuola» Editrice, 1970.

Starobinski, J., L'occhio vivente, Torino, Einaudi Editore, 1975.

Warburg, A., La rinascita del paganesimo antico, Firenze, La Nuova Italia Editrice, 1980. 


\section{ILUSTRACIONES}

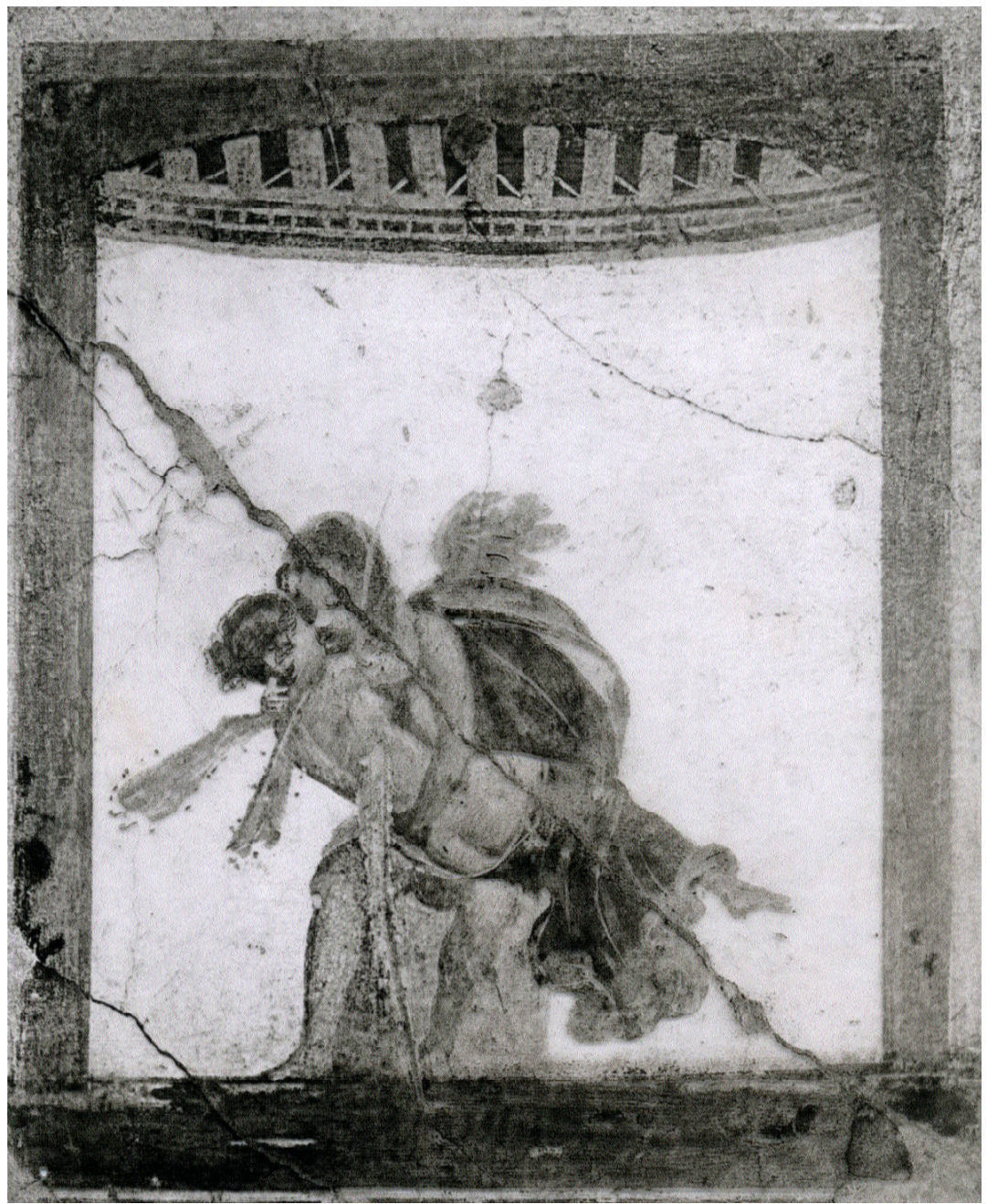

\section{Imagen 1}

Amor y Psique

Primera mitad siglo I d.c.

Napoli, Museo Archeologico Nazionale 


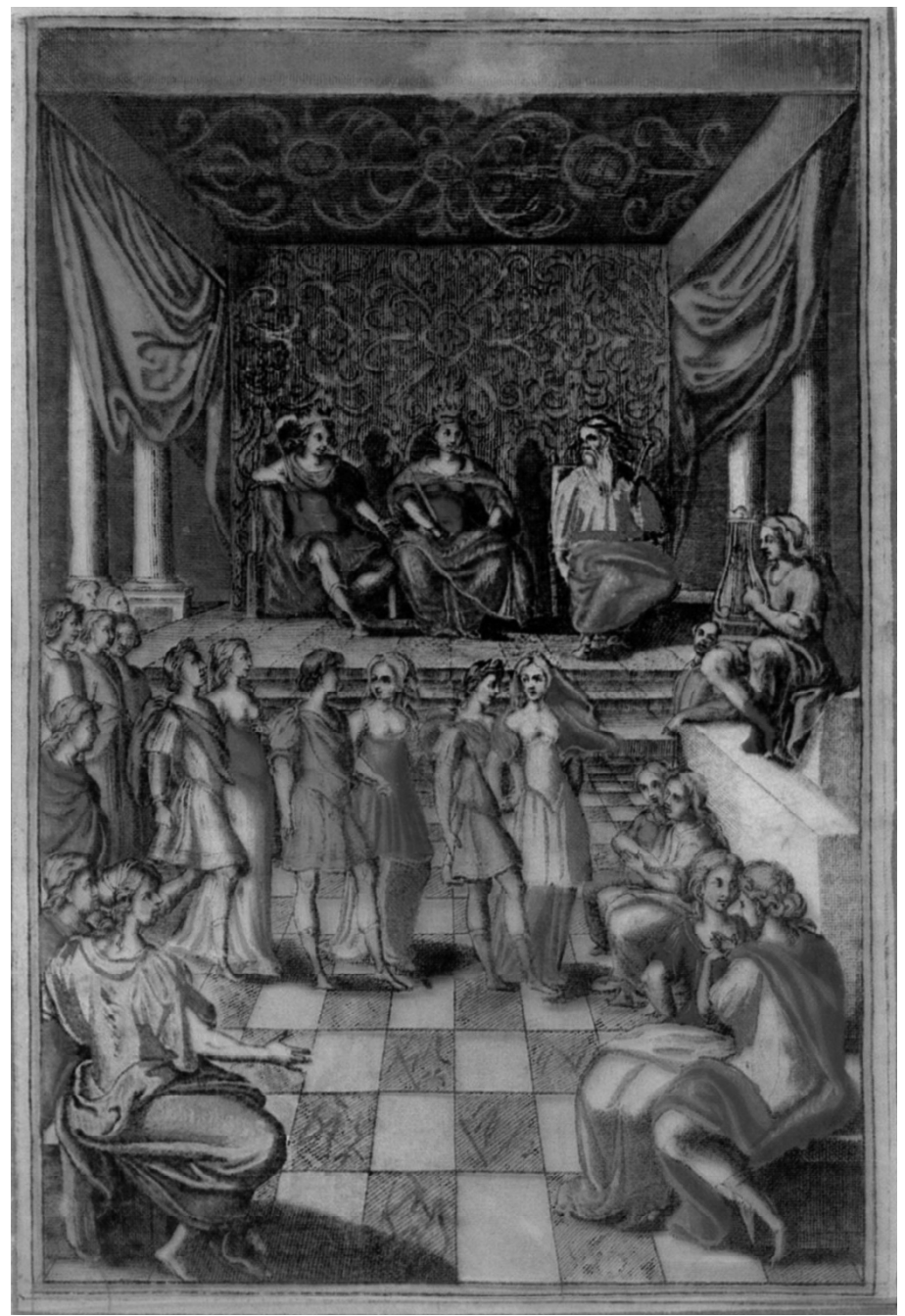

Imagen 2

Jean Puget de Serres

Les Amours du Roy et de la Reyne soubs les noms de Jupiter et de Junon (grabado)

Paris 1625 


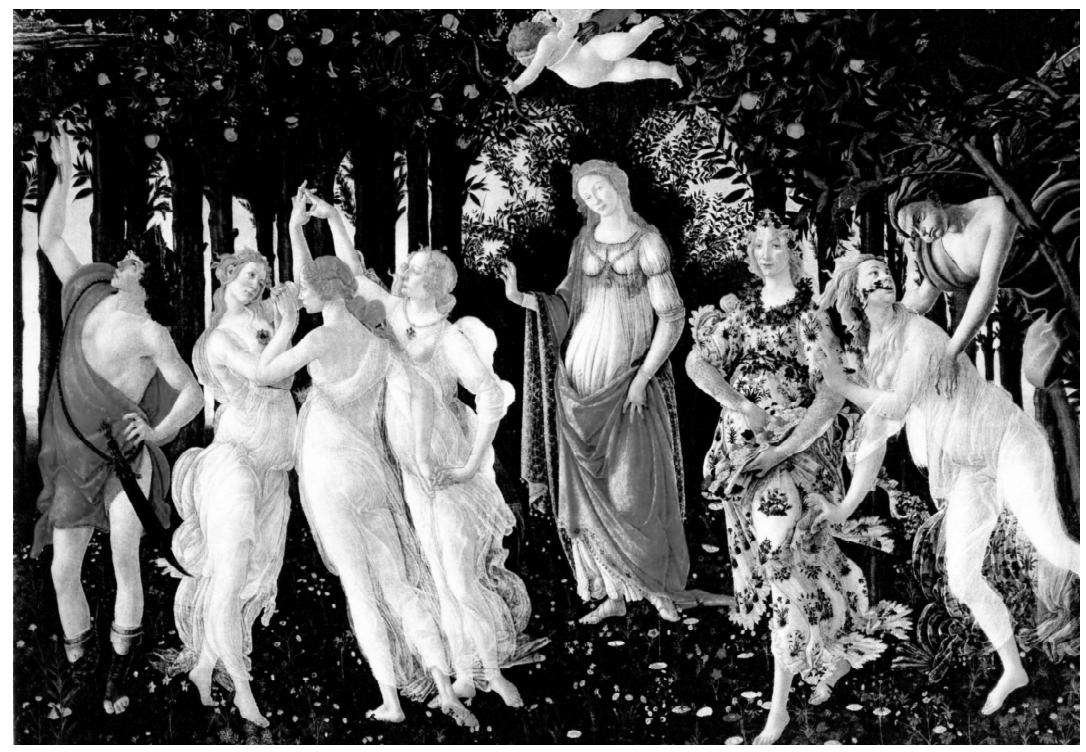

Imagen 3

Botticelli

La Primavera, 1482

Firenze, Galleria degli Uffizi 


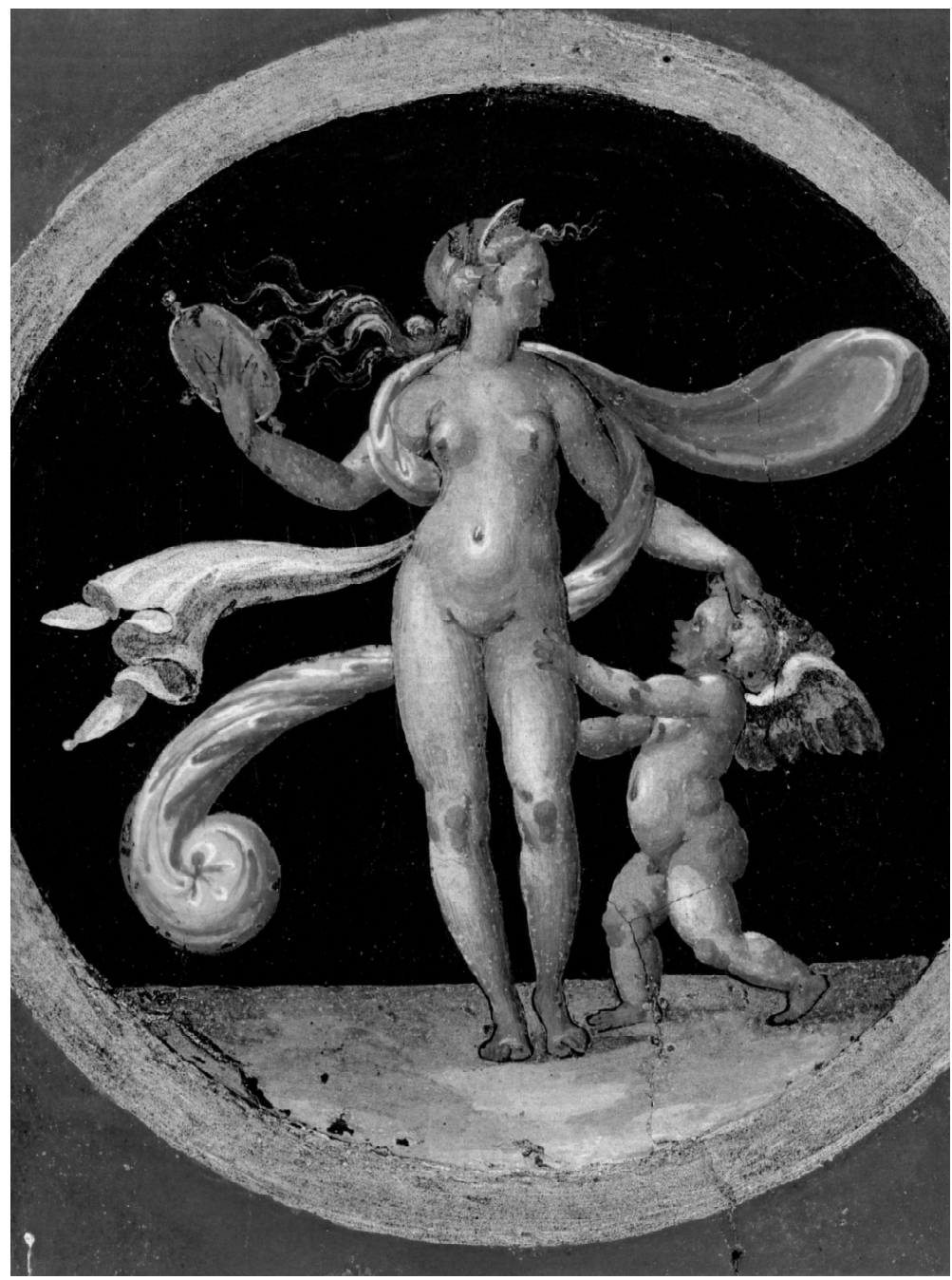

Imagen 4

Giulio Romano

Cuarto de Amor y Psique 1527-1528,

Venus y Amor

Mantova, Palazzo Te 


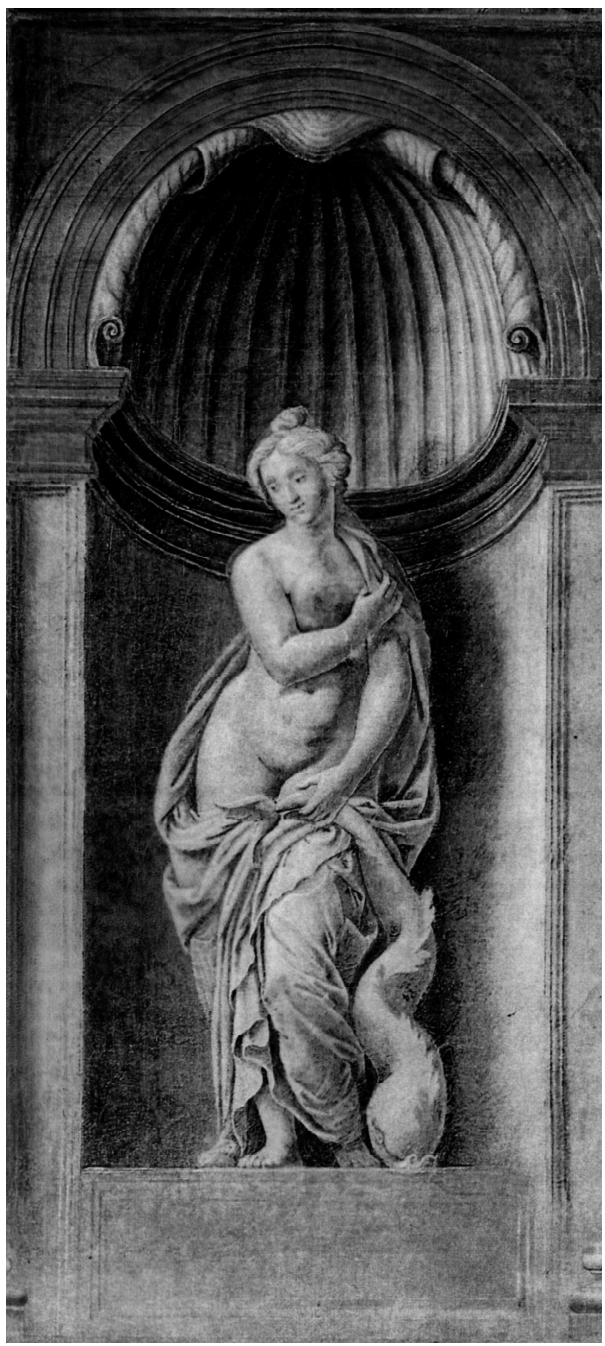

Imagen 5

Giulio Romano

Sala de los Caballos, Venus

Mantova, Palazzo Te 

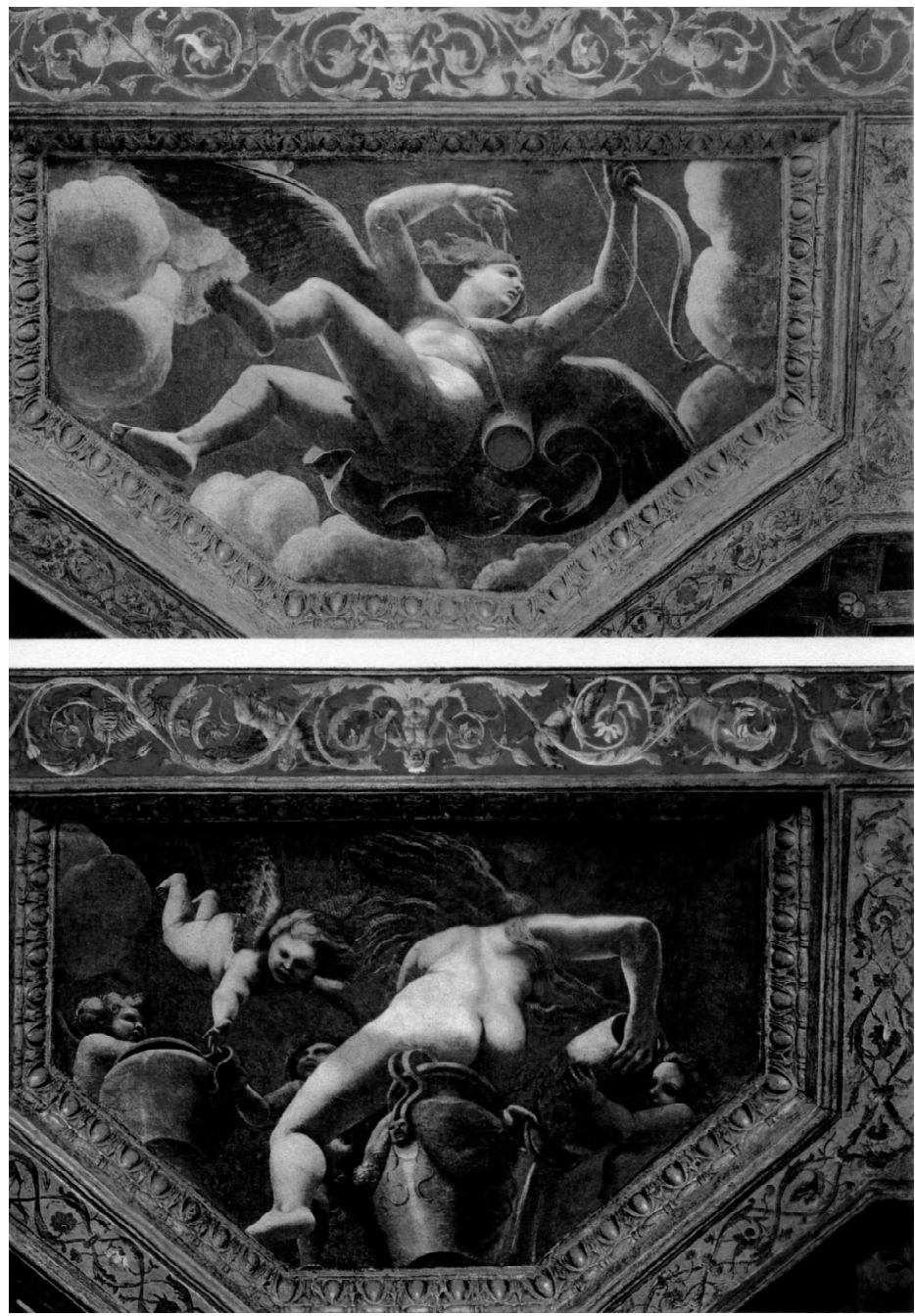

Imagen 6

Giulio Romano

Cuarto de Amor y Psique

Psique hiere a Amor con su misma flecha

Mantova, Palazzo Te 


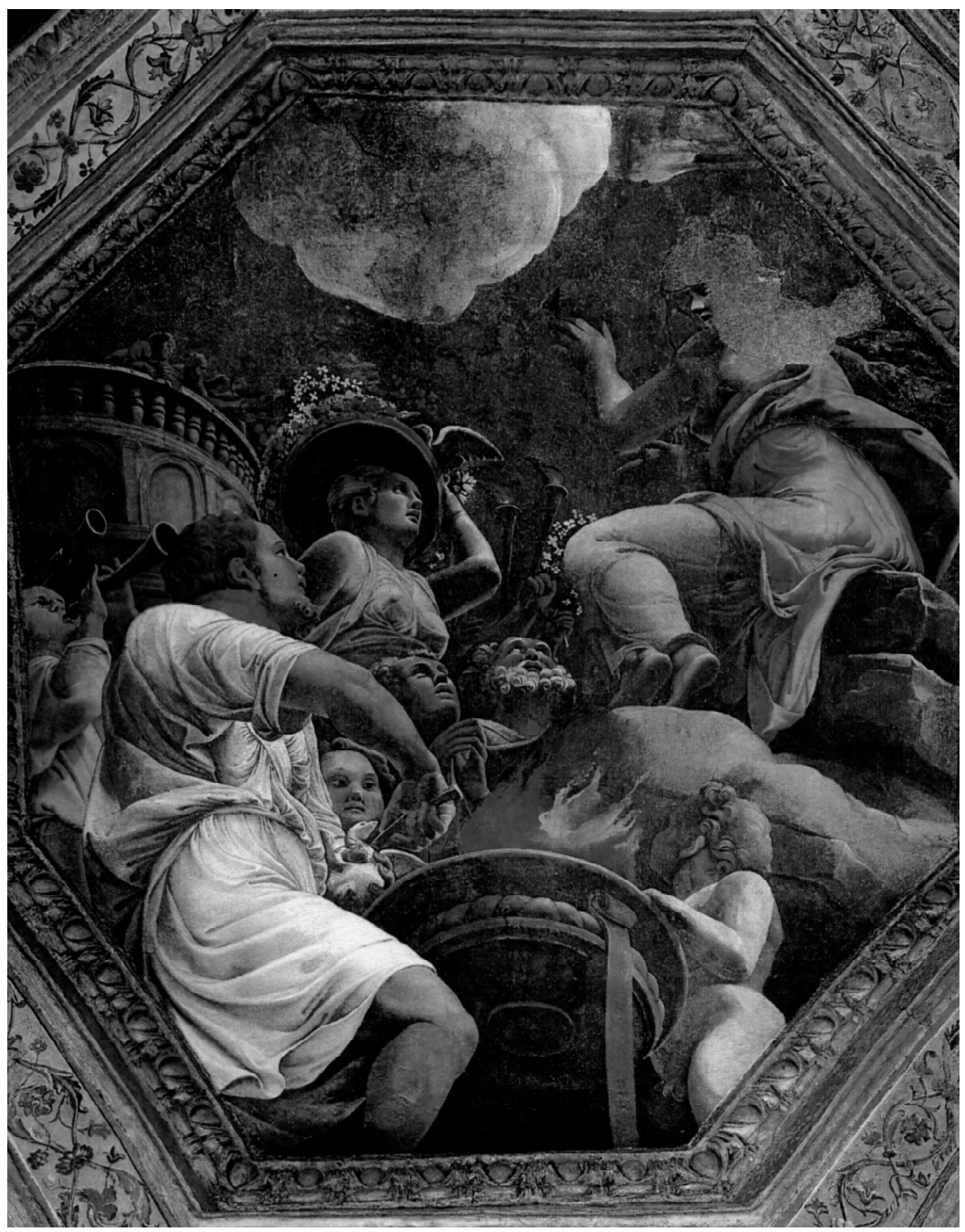

Imagen 7

Giulio Romano

Cuarto de Amor y Psique

Psique venerada como una divinidad

Mantova, Palazzo Te 


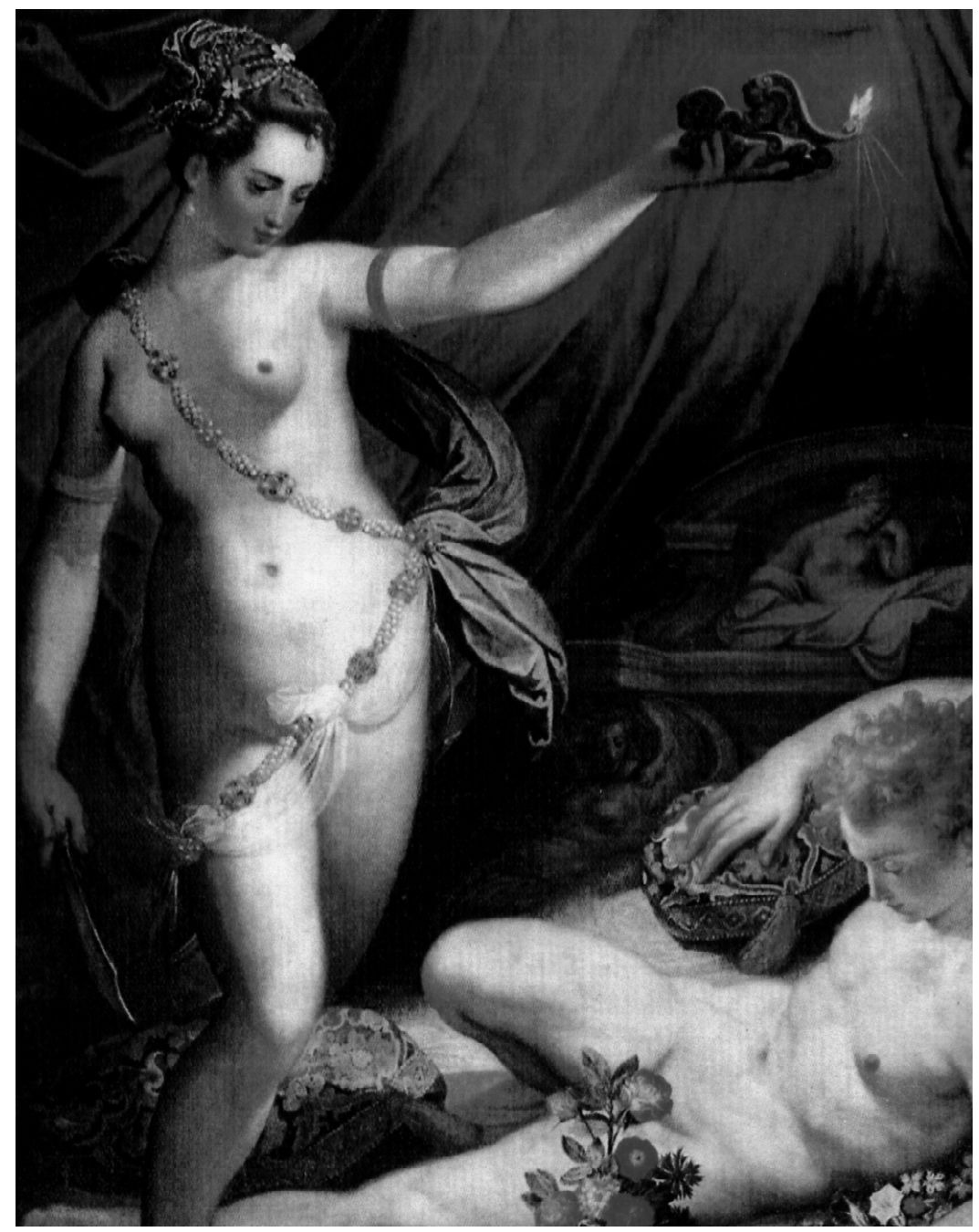

\section{Imagen 8}

Iacopo Zucchi

Amore e Psiche, 1589

Roma, Galleria Borghese 


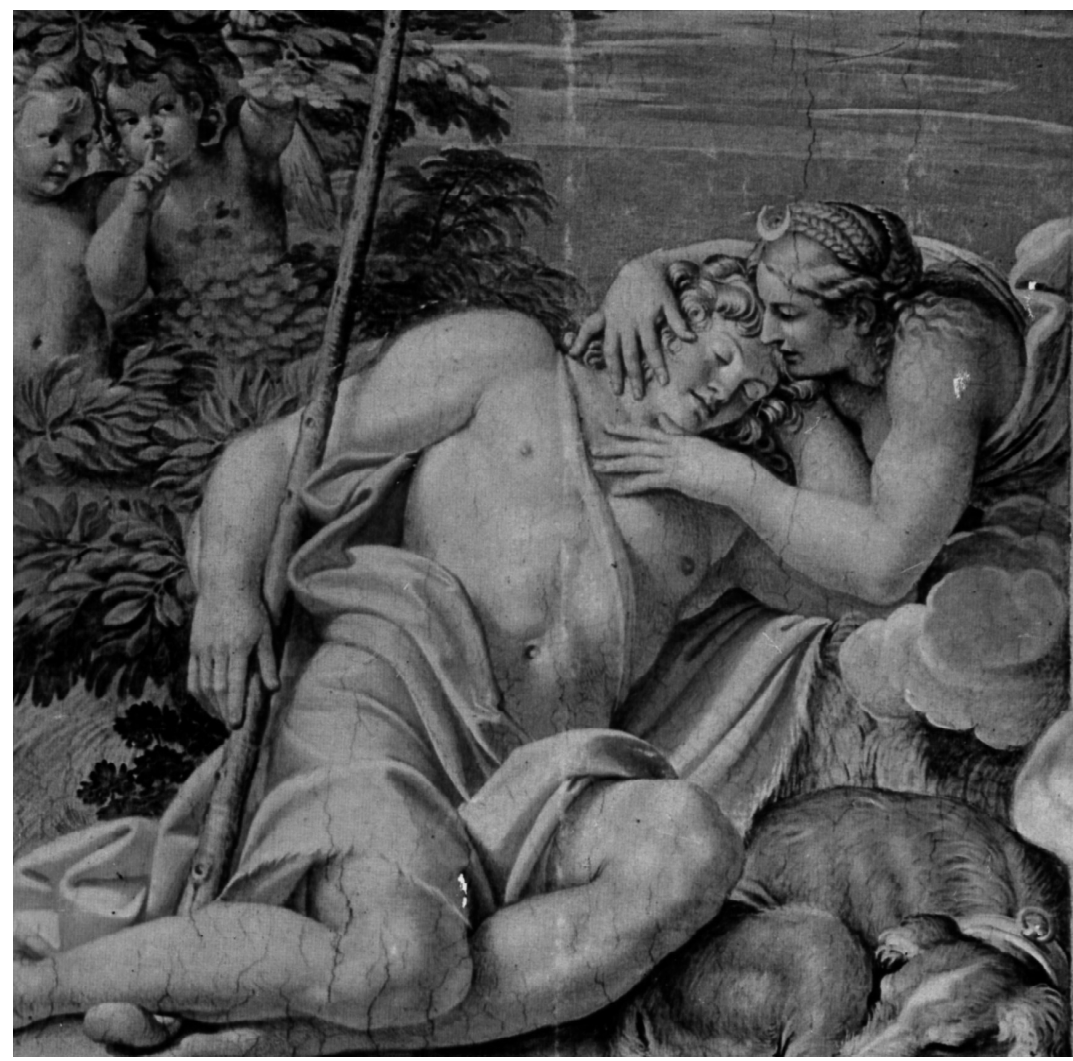

Imagen 9

Annibale Carracci

Diana y Endimión 


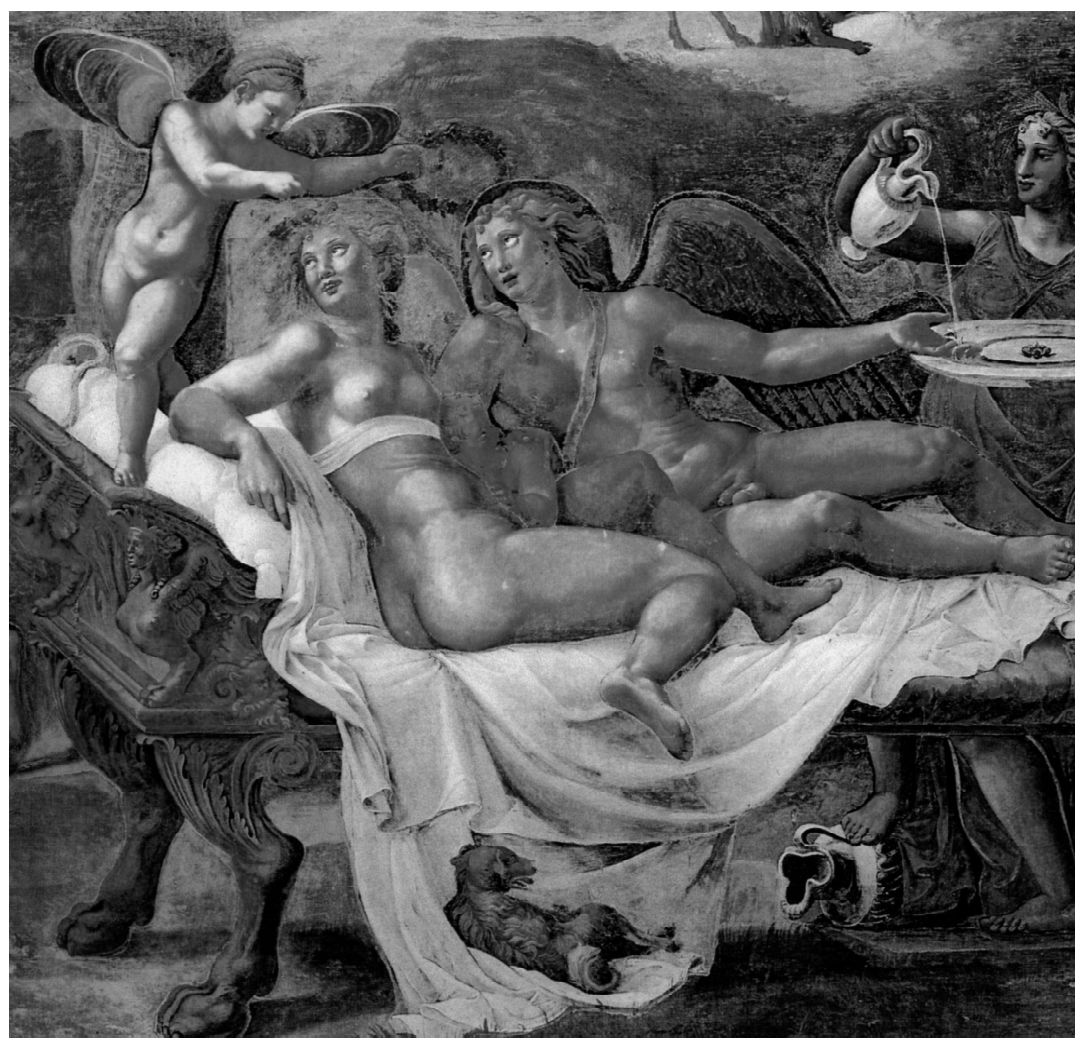

Imagen 10

Giulio Romano

Cuarto de Amor y Psique

Las bodas de Amor y Psique

Mantova, Palazzo Te 